\title{
Possibility of reducing $\mathrm{CO}_{2}$ emissions from internal combustion engines
}

\author{
Dawid Drabik ${ }^{1}$, Jarosław Mamala ${ }^{2,}$, Michat Śmieja ${ }^{3}$, and Krzysztof Prażnowski ${ }^{4}$ \\ ${ }^{1}$ Opole University of Technology, MEng, Faculty of Mechanical Engineering, St. Mikołajczyka 5, 45-271 Opole, Poland \\ ${ }^{2}$ Opole University of Technology, Faculty of Mechanical Engineering, St. Mikołajczyka 5, 45-271 Opole, Poland \\ ${ }^{3}$ University of Warmia and Mazury, Faculty of Technical Sciences, Michała Oczapowskiego 11, 10-719 Olsztyn, Poland \\ ${ }^{4}$ Opole University of Technology, Faculty of Mechanical Engineering, St. Mikołajczyka 5, 45-271 Opole, Poland
}

\begin{abstract}
Article defines on the possibility of reduction $\mathrm{CO}_{2}$ of the internal combustion engine and presents the analysis based on originally conducted studies. The increase in overall engine efficiency is sought after by all engineers dealing with engine construction, one of the major ways to reduce $\mathrm{CO}_{2}$ emissions is to increase the compression ratio. The application of the compression ratio that has been increased constructional in the engine will, on one hand, bring about the increase in the theoretical efficiency, but, on the other hand, require a system for pressure control at a higher engine load in order to prevent engine knocking. For the purposes of the article there was carried out a number of studies and compiled results, and on their basis determined what have a major impact on the reducing $\mathrm{CO}_{2}$.
\end{abstract}

\section{Introduction}

Modern internal combustion engines are built from the point of view of achieving the highest overall efficiency of the entire system. Those aspects that are associated with environmental protection and $\mathrm{CO}_{2}$ reduction are very important in the production of power units. Therefore, automobile manufacturers attempt to design their cars in such a way as to ensure their cars are fuelefficient and have good responsiveness. There are many ways to reduce $\mathrm{CO}_{2}$, starting from those directly related to the engine and ending with the design of bodywork. Currently the race associated with automobile development is on. Internal combustion engines are still the most common units that transform fuel energy into mechanical energy. However, it should be kept in mind that traditional fuel resources are slowly being depleted; therefore, such a great emphasis is placed on using renewable power sources for cars [2].

Gasoline contains carbon and hydrogen atoms. During combustion, the carbon (C) from the fuel combines with oxygen $\left(\mathrm{O}_{2}\right)$ from the air to produce carbon dioxide $\left(\mathrm{CO}_{2}\right)$. Emission of carbon dioxide is directly connected with fuel consumption. Therefore, if fuel consumption is reduced, emission of carbon dioxide decreases. Engines are adjusted in order to minimize fuel consumption. $2.3 \mathrm{~kg}$ of carbon dioxide is produced from burning $1 \mathrm{~kg}$ of fuel.

With all of the above information in mind, as well as the fact that the search process for alternative sources to power engines is very dynamic, it can be stated that a traditional four-stroke engine will be the most popular unit installed in passenger cars for a few years to come.
The development of systems that enhance engine efficiency is already very advanced. New solutions to improve engines as units that transform fuel energy into mechanical energy are still being produced.

\section{Efficiency of internal combustion engines}

The efficiency of the internal combustion engine is an extremely important indicator of engine operation and it is connected with the possibility of reducing fuel consumption. Engineers aim at raising the efficiency since it facilitates better use of energy obtained from fuels. The main function of the internal combustion engine is to transform fuel energy into mechanical energy [4]. Overall engine efficiency is defined:

$$
\eta_{o}=\eta_{i} \cdot \eta_{m} \cdot \eta_{t}
$$

Considerations on engine efficiency should begin with the determination of theoretical efficiency $\eta_{t}$, which is defined as a ratio of the work of theoretical cycle $L_{t}$ to the entire heat energy provided for the engine in one cycle $Q$ :

$$
\eta_{t}=\frac{L_{t}}{Q}
$$

Efficiency that considers losses in the engine cylinder in respect of actual combustion, compression, decompression, charge exchange and other processes are called indicated efficiency. Indicated efficiency can be

\footnotetext{
Corresponding author: j.mamala@po.edu.pl
} 
presented using two equations: as a ratio of indicated work $L_{i}$ to theoretical work $L_{t}$ :

$$
\eta_{i}=\frac{L_{i}}{L_{t}}
$$

or

$$
\eta_{i}=\frac{3600 \cdot N_{i}}{\eta_{t} \cdot G_{e} \cdot W}
$$

where:

$N_{i}$ - indicated power,

$G_{e}$ - hourly fuel consumption in $\mathrm{g} / \mathrm{h}$ or $\mathrm{kg} / \mathrm{h}$,

$W$ - heating value of fuel $\mathrm{kJ} / \mathrm{kg}$,

Mechanical efficiency takes into account losses resulting from friction in the engine system and is defined as a ratio of useful work $L_{e}$ to indicated work $L_{i}$

$$
\eta_{m}=\frac{L_{e}}{L_{i}}
$$

Total efficiency of internal combustion engine is defined:

$$
\eta_{o}=\frac{L_{e}}{Q_{d}}
$$

The results of petrol and diesel engine efficiency are presented in Table 1.

Table 1. Results of petrol and diesel engine efficiency [4].

\begin{tabular}{|c|l|l|}
\hline Efficiency & $\begin{array}{l}\text { Spark } \\
\text { ignition } \\
\text { engine }\end{array}$ & Diesel \\
\hline $\begin{array}{c}\text { Theoretical efficiency } \\
\eta_{t}\end{array}$ & $0.35-0.45$ & $0.50-0.65$ \\
\hline $\begin{array}{c}\text { Indicated efficiency } \\
\eta_{i}\end{array}$ & $0.65-0.78$ & $0.75-0.85$ \\
\hline $\begin{array}{c}\text { Mechanical efficiency } \\
\eta_{m}\end{array}$ & $0.75-0.85$ & $0.75-0.80$ \\
\hline $\begin{array}{c}\text { Overall efficiency } \\
\eta_{0}\end{array}$ & $0.20-0.32$ & $0.28-0.45$ \\
\hline \multicolumn{2}{|c|}{} \\
\hline
\end{tabular}

One of the ways to enhance overall efficiency is to charge the compression ratio. Raising the compression ratio yields a number of positive results. Overall efficiency describes all losses in the engine.

In order to determine overall engine efficiency accurately, a complex formula considering the most important variables should be used:

$$
\eta_{o}=\frac{1}{g_{e} \cdot W_{d}}
$$

It can be stated that specific fuel consumption is a measure of overall engine efficiency. The research carried out by the authors showed that a direct increase in the compression ratio has an impact on the reduction of fuel consumption [4].

The $\mathrm{CO}_{2}$ emission standards have become more strict over the years. It is connected with a considerable danger caused by emission of carbon dioxide. Fig. 1 presents changes in the $\mathrm{CO}_{2}$ emission standards implemented over the years [3].

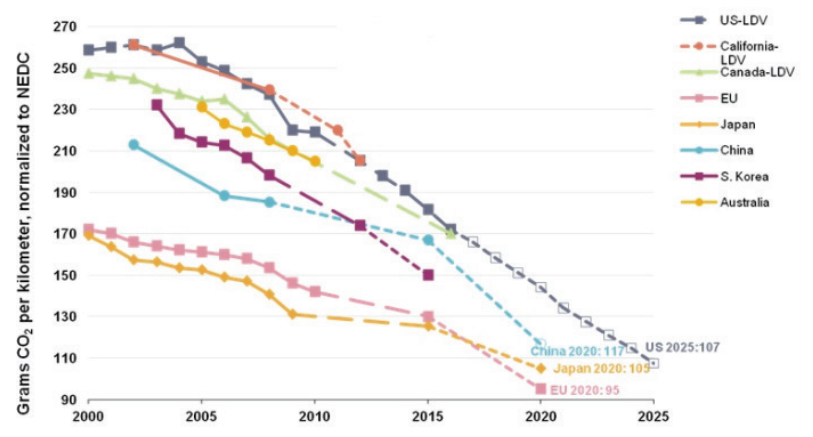

Fig. 1. The trend of carbon dioxide emission standards for passenger cars [9].

\section{Solutions for dealing with emission of carbon dioxide}

It is impossible and unprofitable to increase the compression ratio in an engine continuously. The possibilities of increasing the compression ratio in a petrol engine are limited mainly by a chance that a phenomenon called engine knocking occurs, which leads to serious damage to the engine design. Strength conditions and the occurrence of mechanical losses due to the compression ratio being too high cause the compression ratio to be in the range of 9 to 14 for petrol engines.

The results to be obtained by the increase in the compression ratio are so promising that many companies are trying to design an engine with a variable compression ratio. The engine built by French company MCE-5 is very promising as its compression ratio is controlled by the change of the volume of the combustion chamber with a very complex system. The presented results confirm a significant reduction of fuel consumption and carbon dioxide emission and, simultaneously, the increase in torque and power. Fig. 2 shows MCE-5 Engine VCRi.
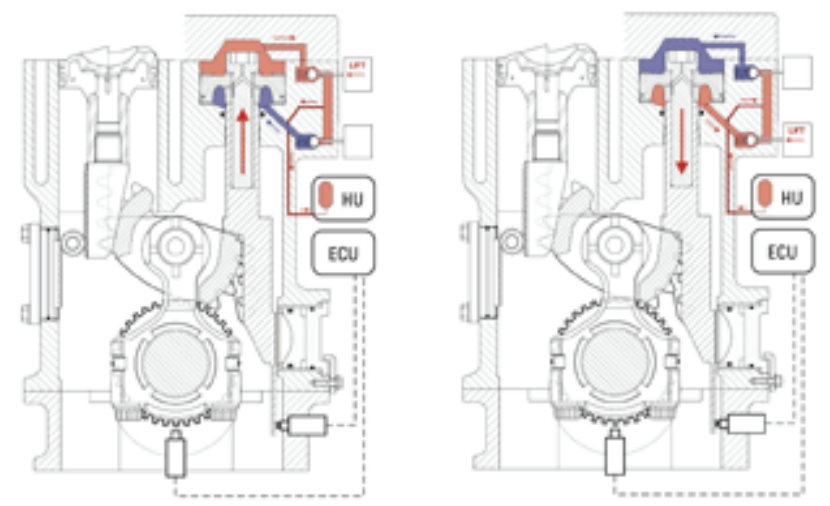

Fig. 2. MCE-5 Engine VCRi [6].

A decrease of fuel consumption in a combustion chamber is a result of these adjustments. Fig. 3 presents adjustments made in v6 engine to reduce emission of carbon dioxide. 


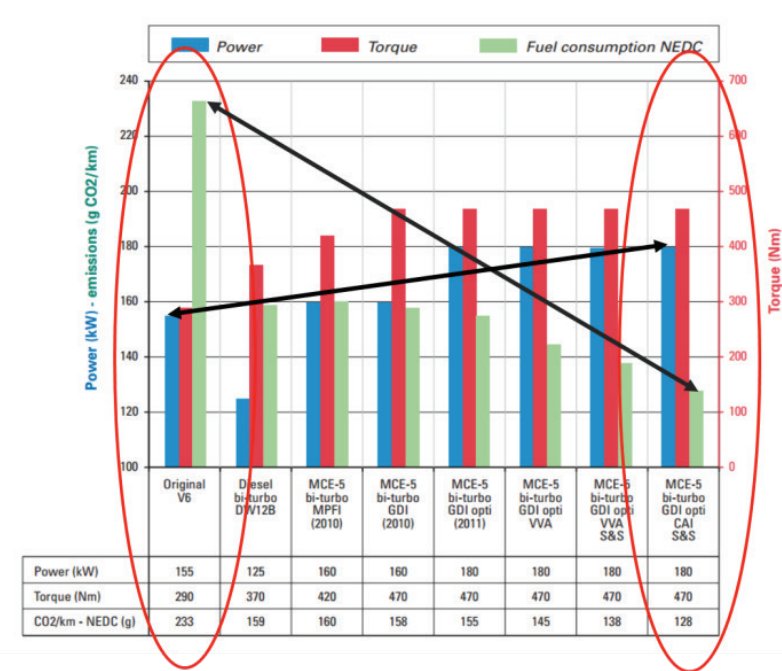

Fig. 3. Key results of original V6 engine and MCE-5 Engine VCRi bi-turbo GDI opti CAI [6].

Results:

- On a Peugeot 407 type vehicle, the most basic MCE-5

VCRi MPFI reduces $\mathrm{CO}_{2}$ emissions by $45 \%$.

- $16 \%$ more power.

- $62 \%$ more torque.

Other engines that are based on the idea of variable compression ratio are Scuderii Engine and SVC (SAAB Variable Compression). The compression ratio ideal for the engine in a given moment depends on road conditions. Fig. 4 shows a map of optimal compression ratio depending on the driving style.

\section{C.R. control map}

(Engine operating conditions)

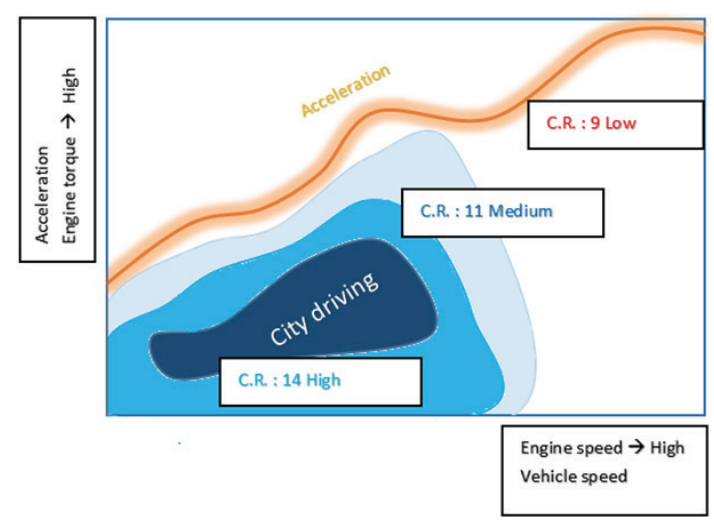

Fig. 4. Map of optimal compression ratio for an appropriate driving style [2].

The engine constructed by Infinity will be serially mounted in cars. The idea presented by Infinity engineers is based on changing the volume of a combustion chamber [1]. It adjusts compression ratio to the road conditions. A mass of a vehicle has a considerable influence on fuel consumption. Fig. 5 presents a relationship between a vehicle mass and fuel consumption.

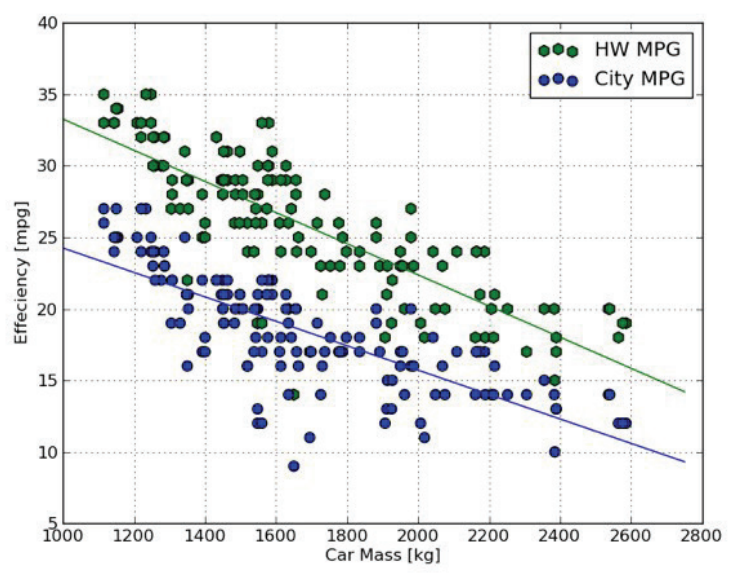

Fig. 5. Impact Car Mass on efficiency [9].

Internal combustion engines are constantly being developed. The following factors influence the development of engines:

- modern materials,

- modern oils and fuels,

- exhaust fumes emission norms,

- hybrid technology,

- modern electronic systems [4].

The internal combustion engine is a design that has evolved over the years. The first engines did not have high power or torque. Engine performance parameters say what characterises a given power unit [5].

The term engine indication mainly refers to measurements of pressure in the cylinder. Appropriate use of indication techniques gives the possibility of observing the phenomena occurring in the combustion chamber at low cost. A pressure measurement usually involves a full operating cycle of the engine [7]. Fig. 6 shows an open theoretical indicator diagram of an internal combustion engine for the two compression ratio, calculated using a computer, whereas shows an open indicator diagram for the two compression ratio. By carrying out laboratory tests, it can be stated that pressure in the combustion chamber can be modified. This translates into changes in power, torque or specific fuel consumption. Fig. 7 shows an opened actual indicator diagram

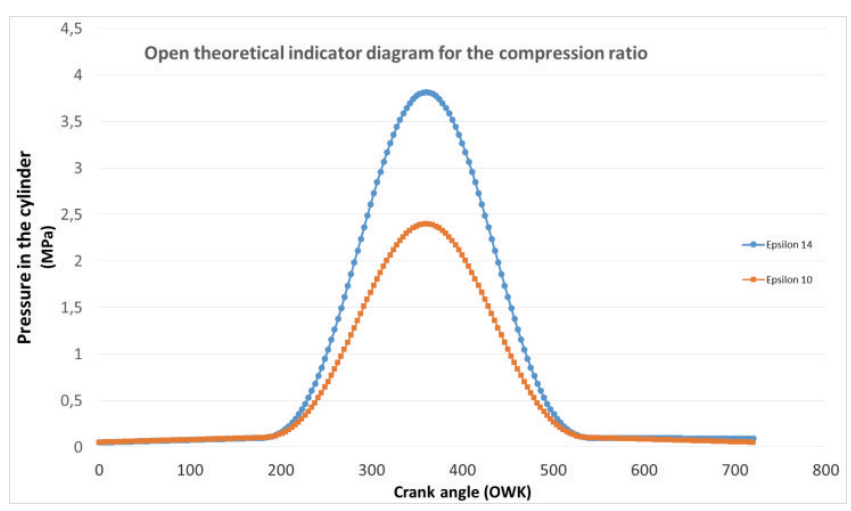

Fig. 6. Open theoretical indicator diagram for the different compression ratio. 


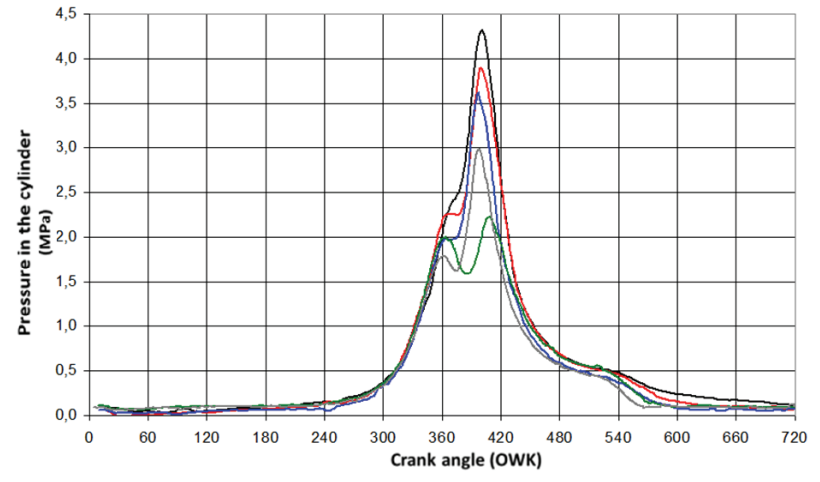

Fig. 7. Opened actual indicator diagram obtained by the change of the compression ratio.

The decrease in the compression ratio has a direct impact on the reduction of pressure in the cylinder. The increase of the compression ratio from 10 to 14 results in the raise of the pressure peak in a rate of $40 \%$. Changes of the pressure in the cylinder enable a number of various analyses to be performed. Indication parameters can be divided into two categories:

- indirect indication parameters,

- direct indication parameters [8].

The difference between these two categories is such that direct indication parameters are determined from the pressure curve during one cycle. Indirect indication parameters require a number of calculations to be determined.

Increasing the compression ratio permanently results in high pressures without the need for an extensive charging system. However, this requires a solution that allows the operation of such a full engine load. Therefore, this work describe a system has been proposed to change the effective compression ratio of the internal combustion engine.

\section{Conclusions}

Overall efficiency is one of the most important engine performance parameters. It is obvious that the highest efficiency is much desired. There are many methods of increasing overall efficiency of an internal combustion engine. One of the methods, which yields very good results, is to increase the compression ratio. Unfortunately, it is road conditions that determine if the compression ratio rate. Modern engines that are installed as standard in passenger cars have a fixed compression ratio. However, there are innovative engine designs that are characterised by variable compression ratio. These engines include: MCE-5, Scuderii Engine, SVC SAAB or Infinity Engine. All tests were performed on the dynamometer. The results show that increasing the compression ratio improves the overall efficiency of the engine. The results confirm that as the compression ratio increases, the pressure in the cylinder rises.

By examining engine performance parameters, it is possible to choose such areas to be modified so that overall efficiency can be higher. Open indicator diagrams show that the higher compression ratio is assumed, the higher the pressure in the system is. This translates into the increase in overall engine efficiency. Higher compression ratio also involves lower specific fuel consumption, and lower fuel consumption means lower carbon dioxide emission into the environment.

This is an important issue that despite the growing interest in electric drive, the internal combustion engine will remain the main source of power vehicles. Car manufacturing is constantly increasing, hence the increasing production of engines. Currently around 90 million power units are produced yearly; however, it is possible that 125 million power units will be produced yearly in 2025 .

The production of internal combustion engines will increase dramatically in the following years, which is an economic motivation for manufacturers. New solutions to enhance overall increase engine efficiency and reduced $\mathrm{CO}_{2}$ are still being worked towards. Studies into the possibilities of engine development are becoming more and more expensive due to the fact that processes taking place in a power unit need to be examined more and more thoroughly. The authors are working on creating a new engine that will have a variable compression ratio. The whole purpose of the work is to show how important it is to increase the compression ratio and why compression rates cannot be high all the time.

\section{References}

1. A. Bieniek, J. Mamala, M. Graba, Możliwości wstępnego ograniczenia emisji NOx $i$ PM silnika wysokoprężnego $w$ aspekcie przyszłościowych norm emisji pojazdów pozadrogowych, 75, (Zeszyty Naukowe Instytutu Pojazdów, 2012)

2. D. Drabik, J. Mamala, Effective compression ratio of combustion engine as a way of increasing efficiency (Journal of KONES 2016)

3. M. Graba, A. Bieniek, J. Mamala, A. Lechowicz, Inżynieria Rolnicza, 75 (2011)

4. S. Luft, Podstawy budowy silników, 15 (1-3), (Wydawnictwa Komunikacji i Łączności, 2011)

5. J. Mamala, Kompensacja niedostatku sity napęowej $w$ procesie rozpędzania samochodu osobowego, (Wydawnictwo Politechniki Opolskiej, 2011)

6. MCE-5 Development: www.mce-5.com

7. J. Mysłowski, Doładowanie silników Pojazdy samochodowe, 33, (Oficyna Wydawnictwa Komunikacji i Łączności WKŁ Warszawa, 2011)

8. M. Sobieszczański, Modelowanie procesów zasilania $w$ silnikach spalinowych, 13, (Wydawnictwo Komunikacji Łączności, Warszawa 2000)

9. www.acea.be $(11.07 .2017)$ 